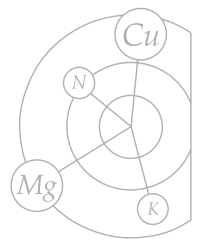

Diviš P., Pořízka J., Vespalcová M., Matějíček A., Kaplan J. 2015. Elemental composition of fruits from different Black elder (Sambucus nigra L.) cultivars grown in the Czech Republic. J. Elem., 20(3): 549-557. DOI: 10.5601/ jelem.2015.20.1.758

ORIGINAL PAPERS

\title{
ELEMENTAL COMPOSITION OF FRUITS FROM DIFFERENT BLACK ELDER (SAMBUCUS NIGRA L.) CULTIVARS GROWN IN THE CZECH REPUBLIC"
}

\author{
Pavel Diviš ${ }^{1}$, Jaromír Pořízka ${ }^{1}$, Milena Vespalcová ${ }^{1}$, \\ Aleš Matějíček ${ }^{2}$, Jiř́i Kaplan² \\ ${ }^{1}$ Department of Food Chemistry and Biotechnology \\ Brno University of Technology, Faculty of Chemistry \\ ${ }^{2}$ Research and Breeding Institute of Pomology, Holovousy Ltd.
}

\begin{abstract}
Black elder is a deciduous shrub widely used in medicine, pharmacy and food industry. This study presents a comparison of the elemental composition of fruits (berries) from the Black elder (Sambucus nigra L.) cultivars Albida, Bohatka, Dana, Heidegg13, Mammut and Sambo, grown in the Czech Republic and harvested in two seasons (2011 and 2013). The fruits were collected at full maturity from an experimental orchard at the Research and Breeding Institute of Pomology, Holovousy Ltd. The raw material was decomposed using hot nitric acid and the determination of the elemental content $(\mathrm{Ca}, \mathrm{K}, \mathrm{P}, \mathrm{Zn} . \mathrm{Cu}, \mathrm{Mn}, \mathrm{Na}, \mathrm{Mg})$ was performed by inductively coupled atomic emission spectrometry in accordance with a valid ISO standard.

Concentration of all the analyzed elements in the various Sambucus nigra cultivars was different, and the differences were statistically significant $(p<0.05)$. All the investigated cultivars were a good source of major and trace elements. The concentration of the analyzed elements in Sambucus nigra decreased in the following order $\mathrm{K}>\mathrm{Ca}>\mathrm{P}>\mathrm{Mg}>\mathrm{Na}>\mathrm{Fe}>\mathrm{Mn}>\mathrm{Zn}>\mathrm{Cu}$. The results demonstrated that Sambucus nigra fruits can be used as functional food in prevention and treatment of diseases associated with deficiency of elements in the human diet. On average, $100 \mathrm{~g}$ of Sambucus nigra fruits can cover about $20 \%$ of the recommended dietary allowance of main elements for women and men. In terms of the content of individual elements, the cultivars Albida and Sambo have proven to be most promising. The chemical composition of Sambucus nigra varied with the year of harvest, but the variation in the elemental content did not exceed $20 \%$ in most cases.
\end{abstract}

Keywords: Sambucus nigra, elderberry, fruit, major and minor metals, spectrometry.

assoc. prof. Pavel Diviš, PhD, Department of Food Chemistry and Biotechnology, Brno University of Technology, Purkyňova 118, 61200 Brno, Czech Republic, e-mail: divis@fch.vutbr.cz * This work was supported by project NP MZe CR 206553/2011-17253 and infrastructure of the projects CZ.1.05/2.1.00/03.0116 and CZ.1.05/2.1.00/01.0012 was used during this work. 


\section{INTRODUCTION}

Black elder (Sambucus nigra L.) is one of the neglected crops in the Czech Republic, but with great potential for use. From a total of approximately 25 species of the genus Sambucus naturally widespread or introduced in all regions around the world, only Sambucus nigra bearing edible fruit which has a natural range of occurrence covering the Czech Republic.

Sambucus nigra is a tall, tree-like shrub, native to Europe, Asia and North Africa, and naturalized in the USA. In the USA, it is known as Sambucus nigra L. ssp. canadiensis (CHARLEBoIs et al. 2010). The shrub blooms during the early summer with small, white flowers creating flat, compound umbels that develop into shiny, purplish-black berries by late summer and early fall (AtKinson, AtKinson 2002, ChaRlebois et al. 2010). Elder flowers and fruits have been known for centuries for their healing properties. Elder flowers and berries are rich in beneficial ingredients such as flavonoids, polyphenolic compounds, different organic acids, anthocyanins or ascorbic acid, which help to prevent or treat cancer, cardiovascular diseases or neurodegenerative disorders (MA, Wu 2012, CAVERo et al. 2013, Folmer et al. 2014). Elder flowers are used mainly for preparation of extracts rich in flavonoids and phenolic compounds (CHRISTENSEN et al. 2008); other than that, elder berries are also widely used in food industry to produce elderberry jam, yoghurt, juice or wine (KaAcK, Austed 1998, KaAcK et al. 2008, Charlebois et al. 2010, Schmitzer et al. 2010). Owing to the high content of anthocyanins, elderberry juice is also used as a natural food colouring agent (ZAFRILLA et al. 1998, HubBermann et al. 2006).

Whereas the composition of elder berries in terms of organic matter is very well described by many authors (JaKobeK et al. 2007, Mratinic, FotiRic 2007, Lee, Finn 2007, Ochmian et al. 2009, Veberic et al. 2009), there is a shortage of studies dealing with the elemental composition of elder berries, although some of the metals they contain play an important role in the human body. Therefore, this study's aim has been to investigate the elemental composition of Black elder (Sambucus nigra L.) berries from six different Sambucus nigra cultivars grown in the Czech Republic.

\section{MATERIAL AND METHODS}

For the calibration of an ICP-OES instrument, certified solutions of the target metals ( $1 \mathrm{~g} \mathrm{dm}^{-3}$, Astasol, Analytika, Czech Republic) were used. Nitric acid (Analpure, Analytika) served for digestion of Sambucus nigra samples. All water used in this study was ultrapure water prepared in an ELGA station (Veolia Watter systems Ltd., UK). Quality control material (QCM) METRANAL No. 3 containing different metals in strawberry leaves matrix 
(Analytika) was used to verify the proper function of the ICP-OES instrument.

All the analyzes were performed on an ICP-OES (Ultima 2, Horiba Jobin Yvon, France) equipped with a Mainhard-type nebuliser and a cyclonic spray chamber. Before the analyses, the ICP-OES operating conditions were optimised by measuring the ratio of the intensities of the magnesium 280 and $285 \mathrm{~nm}$ spectral lines and by measuring the ratio of signal and background (SBR). The optimal wavelengths were chosen from the international standard CSN EN ISO 11885 in order to achieve sufficient sensitivity and the least interference. The optimal conditions for the ICP-OES analysis were: peristaltic pump rotation $20 \mathrm{rpm}$, nebuliser pressure $0.29 \mathrm{MPa}$ and generator power $1200 \mathrm{~W}$. The chosen wavelength and the results from the analyses on QCM are summarized in Table 1. For sample weighing, an analytical balance AND HA-202M (A\&D Company, Japan) was used. Samples were shaken in a GFL 3006 shaker (Gesselschaft für Laboratortechnik mbH, Germany) and heated on a Gerhardt heating plate (Gerhardt Bonn, Germany).

All of the Sambucus nigra cultivars were grown in the Czech Republic, at the Research and Breeding Institute of Pomology Holovousy Ltd. $\left(50^{\circ} 22^{\prime} 29^{\prime \prime} \mathrm{N}, 15^{\circ} 34^{\prime} 38^{\prime \prime} \mathrm{E}, 321 \mathrm{~m}\right.$ alt.), in an experimental orchard established in autumn 2008. The soil in the experimental orchard is heavy loamy clay soil with the minimum thickness of $60-80 \mathrm{~cm}$. The bedrock consists of clay stone. The average annual temperature in the locality is $8.14^{\circ} \mathrm{C}$. The average annual rainfall is $655 \mathrm{~mm}$ and the average rainfall during the plant growing period is $379 \mathrm{~mm}$. No pesticides were used during the cultivation. The Sambucus nigra berries were harvested at full maturity, at the end of August 2011 and 2013 , and stored at $-18^{\circ} \mathrm{C}$ prior to the analyses, which

Table 1

An overview of the wavelengths used for sample analyses on an ICP-OES and results from the analysis of quality control material Metranal 3 (arithmetic mean \pm standard deviation)

\begin{tabular}{|c|c|c|c|c|}
\hline Element & $\begin{array}{c}\text { ICP-OES } \\
\text { wavelenght } \\
(\mathrm{nm})\end{array}$ & $\begin{array}{c}\text { QCM } \\
\text { certified value } \\
\left(\mathrm{mg} \mathrm{kg}^{-1}\right)\end{array}$ & $\begin{array}{c}\text { QCM } \\
\text { Real value } \\
\left(\mathrm{mg} \mathrm{kg}^{-1}\right)\end{array}$ & $\begin{array}{c}\text { Recovery } \\
(\%)\end{array}$ \\
\hline $\mathrm{Zn}$ & 206.191 & $27.1 \pm 1.8$ & $24.4 \pm 1.6$ & 90 \\
\hline $\mathrm{Mn}$ & 257.610 & $187 \pm 18$ & $174 \pm 21$ & 93 \\
\hline $\mathrm{Fe}$ & 259.940 & $912 \pm 90$ & $866 \pm 55$ & 95 \\
\hline $\mathrm{Mg}$ & 285.213 & $4210 \pm 420$ & $4294 \pm 379$ & 102 \\
\hline $\mathrm{Cu}$ & 324.750 & $8.68 \pm 0.76$ & $8.33 \pm 0.69$ & 96 \\
\hline $\mathrm{P}$ & 213.618 & n.a. & $*$ & $*$ \\
\hline $\mathrm{Ca}$ & 422.673 & n.a. & $*$ & * \\
\hline $\mathrm{Na}$ & 588.900 & n.a. & $*$ & $*$ \\
\hline $\mathrm{K}$ & 766.490 & $21200 \pm 2100$ & $22472 \pm 1932$ & 106 \\
\hline
\end{tabular}

n.a. - not available 
were performed as soon as possible. The analyzed cultivars of Sambucus nigra were: Albida, Bohatka, Dana, Heidegg13, Mammut and Sambo. Basic characterisation of the cultivars is given in Table 2.

Table 2

Characterization of Sambucus nigra cultivars examinated in this study

\begin{tabular}{|l|c|c|c|c|}
\hline \multicolumn{1}{|c|}{ Cultivars } & $\begin{array}{c}\text { Fruit mass* } \\
(\mathrm{g})\end{array}$ & $\begin{array}{c}\text { Dry mass } \\
(\%)\end{array}$ & $\begin{array}{c}\text { Reducing } \\
\text { sugars } \\
(\%)\end{array}$ & $\begin{array}{c}\text { Titratable } \\
\text { acidity*** } \\
\left(\mathrm{g} \mathrm{kg}^{*-1}\right)\end{array}$ \\
\hline Albida & 22.2 & 16.1 & 5.2 & 27.2 \\
\hline Bohatka & 38.5 & 14.3 & 4.9 & 25.7 \\
\hline Dana & 39.6 & 13.6 & 5.2 & 22.8 \\
\hline Heidegg 13 & 39.6 & 15.3 & 3.0 & 32.7 \\
\hline Mammut & 39.3 & 14.5 & 5.4 & 30.4 \\
\hline Sambo & 39.4 & 14.6 & 2.8 & 44.0 \\
\hline
\end{tabular}

*-infructescences mass, ${ }^{* *}$ - expressed as citric acid - all values are expressed as an average

Approximately one gram of Sambucus nigra berries was weighed out on an analytical balance and each sample was transferred to a $0.05 \mathrm{dm}^{-3}$ Erlenmayer flask. A total amount of $0.02 \mathrm{dm}^{-3}$ of nitric acid was added to each sample and the samples were shaken overnight. After shaking, the Erlenmayer flasks with the samples were transferred on a heating plate and heated for 60 min until complete decomposition of the samples. After cooling down, the samples were transferred into $0.1 \mathrm{dm}^{-3}$ volumetric flasks and filled up with deionised water. Each of the Sambucus nigra cultivar was decomposed and analyzed three times. The same procedure was applied to prepare quality control material samples.

All concentrations were expressed as means and the standard deviation. The concentrations in $\mathrm{mg} \mathrm{kg}^{-1}$ were calculated from the equation 1 :

$$
c_{m}=c_{s} V / m
$$

where $c_{m}$ is the concentration of a given element in $\mathrm{mg} \mathrm{kg}^{-1}, c_{s}$ - the concentration of this element in the analyzed solution $\left(\mathrm{mg} \mathrm{dm}^{-3}\right), V-$ the volume of the analyzed solution $\left(\mathrm{dm}^{3}\right)$ and $m$ - the weight of the sample used for the analysis $(\mathrm{kg})$. The data were further analyzed with the XLStat and Microsoft Excel software. Testing for the significance of mean effects and interactions on all variables was accomplsihed using Anova analysis of variance and the Tukey's test. Statistical significance was set at $P=0.05$.

\section{RESULTS AND DISCUSSION}

The results from the analyses of Sambucus nigra cultivars harvested in 2011 are summarized in Table 3. The content of all the elements, except cop- 
Table 3

Mineral content in Sambucus nigra cultivars harvested in 2011 (mg kg-1 fresh weight)

\begin{tabular}{|c|c|c|c|c|c|c|}
\hline \multirow{2}{*}{ Element } & \multicolumn{6}{|c|}{ Cultivar } \\
\cline { 2 - 7 } & Albida & Bohatka & Dana & Heidegg13 & Mammut & Sambo \\
\hline $\mathrm{Ca}$ & $1008 \pm 32^{b c}$ & $1080 \pm 64^{b}$ & $885 \pm 12^{c}$ & $906 \pm 20^{c}$ & $938 \pm 15^{c}$ & $1528 \pm 30^{a}$ \\
\hline $\mathrm{K}$ & $4979 \pm 68^{b}$ & $4461 \pm 211^{c}$ & $4397 \pm 50^{c}$ & $4673 \pm 114^{b c}$ & $4924 \pm 50^{b}$ & $5494 \pm 62^{a}$ \\
\hline $\mathrm{Na}$ & $53 \pm 1^{b}$ & $18.8 \pm 0.8^{d}$ & $34 \pm 1^{c}$ & $146 \pm 5^{a}$ & $20 \pm 1^{d}$ & $19.0 \pm 0.9^{d}$ \\
\hline $\mathrm{P}$ & $872 \pm 23^{b}$ & $735 \pm 21^{c}$ & $823 \pm 17^{b}$ & $818 \pm 31^{b c}$ & $1077 \pm 5^{a}$ & $1131 \pm 36^{a}$ \\
\hline $\mathrm{Mg}$ & $575 \pm 13^{b}$ & $448 \pm 11^{c}$ & $419 \pm 1^{d}$ & $408 \pm 6^{d}$ & $572 \pm 5^{b}$ & $739 \pm 6^{a}$ \\
\hline $\mathrm{Mn}$ & $9.5 \pm 0.4^{a}$ & $5.9 \pm 0.5^{b}$ & $4.7 \pm 0.3^{b c}$ & $3.6 \pm 0.4^{c}$ & $3.9 \pm 0.4^{c}$ & $3.8 \pm 0.4^{c}$ \\
\hline $\mathrm{Fe}$ & $17.6 \pm 0.4^{b c}$ & $19 \pm 1^{b}$ & $17.7 \pm 0.6^{b c}$ & $14 \pm 0,6^{d}$ & $29.8 \pm 0.4^{a}$ & $16.1 \pm 0.4^{c d}$ \\
\hline $\mathrm{Zn}$ & $11.3 \pm 0.5^{a}$ & $5.1 \pm 0.4^{d}$ & $6.6 \pm 0.4^{b c}$ & $5.4 \pm 0.3^{c d}$ & $6.4 \pm 0.4 \mathrm{~b}^{c d}$ & $7.1 \pm 0.4^{b}$ \\
\hline $\mathrm{Cu}$ & $1.81 \pm 0.22^{a}$ & $1.9 \pm 0.3^{a}$ & $1.7 \pm 0.4^{a}$ & $1.8 \pm 0.4^{a}$ & $2.0 \pm 0.5^{a}$ & $1.9 \pm 0.4^{a}$ \\
\hline
\end{tabular}

Values in the same row with different letters are significantly different at $p<0.05$.

per, varied between the cultivars, and the differences were statistically significant $(p<0.05)$. All of the analyzed cultivars had high concentrations of potassium, calcium, magnesium and phosphorus. The highest content of these elements was found in the cultivar Sambo. The concentration of sodium in Heidegg13 was approximately 7 times higher $\left(146 \mathrm{mg} \mathrm{kg}^{-1}\right)$ than the amount of sodium in the other five cultivars. The cultivar Mammut contained the highest concentration of iron $\left(29.8 \mathrm{mg} \mathrm{kg}^{-1}\right)$. The highest concentrations of zinc (11.3 mg kg-1) and manganese $\left(9.5 \mathrm{mg} \mathrm{kg}^{-1}\right)$ were found in cv. Albida. In comparison with the other analyzed elements, the concentration of copper in all Sambucus nigra cultivars was low, $1.9 \mathrm{mg} \mathrm{kg}^{-1}$ on average.

The results from the analyses of Sambucus nigra berries harvested in 2013 are summarized in Table 4. Similarly to the data obtained from the

Table 4

Mineral content in Sambucus nigra cultivars harvested in 2013 ( $\mathrm{mg} \mathrm{kg}^{-1}$ fresh weight)

\begin{tabular}{|c|c|c|c|c|c|c|}
\hline \multirow{2}{*}{ Element } & \multicolumn{6}{|c|}{ Cultivar } \\
\cline { 2 - 7 } & Albida & Bohatka & Dana & Heidegg13 & Mammut & Sambo \\
\hline $\mathrm{Ca}$ & $977 \pm 23^{a b}$ & $885 \pm 25^{b}$ & $944 \pm 45^{a b}$ & $585 \pm 38^{c}$ & $574 \pm 28^{c}$ & $1009 \pm 33^{a}$ \\
\hline $\mathrm{K}$ & $3165 \pm 34^{c d}$ & $2953 \pm 7^{d}$ & $3199 \pm 101^{c}$ & $3863 \pm 8^{b}$ & $4201 \pm 53^{a}$ & $4221 \pm 86^{a}$ \\
\hline $\mathrm{Na}$ & $35 \pm 3^{a}$ & $13.0 \pm 0.4^{c}$ & $18.3 \pm 0.6^{b}$ & $13.7 \pm 0.3^{c}$ & $13.4 \pm 0.4^{c}$ & $13.1 \pm 0.5^{c}$ \\
\hline $\mathrm{P}$ & $1230 \pm 19^{b}$ & $997 \pm 16^{d}$ & $1085 \pm 16^{c}$ & $983 \pm 17^{d}$ & $1337 \pm 21^{a}$ & $1234 \pm 12^{b}$ \\
\hline $\mathrm{Mg}$ & $636 \pm 3^{a}$ & $403 \pm 5^{d}$ & $426 \pm 2^{c}$ & $396 \pm 5^{d}$ & $526 \pm 2^{b}$ & $533 \pm 1^{b}$ \\
\hline $\mathrm{Mn}$ & $8.1 \pm 0,4^{a}$ & $6.3 \pm 0.4^{b}$ & $6,2 \pm 0.4^{b}$ & $4,7 \pm 0.4^{c}$ & $5.4 \pm 0.4^{b c}$ & $6.7 \pm 0.4^{b}$ \\
\hline $\mathrm{Fe}$ & $21 \pm 2^{c}$ & $16.5 \pm 0.5^{d}$ & $84.7 \pm 0.6^{a}$ & $46.6 \pm 0.8^{b}$ & $12.4 \pm 0.4^{e}$ & $44.3 \pm 0.7^{b}$ \\
\hline $\mathrm{Zn}$ & $3.3 \pm 0.4^{a}$ & $3.4 \pm 0.4^{a}$ & $2.86 \pm 0.22^{b}$ & $1.9 \pm 0.3^{c}$ & $2.0 \pm 0.4^{c}$ & $1.9 \pm 0.4^{c}$ \\
\hline $\mathrm{Cu}$ & $1.9 \pm 0.4^{a}$ & $1.8 \pm 0.5^{a}$ & $2.4 \pm 0.4^{b}$ & $1.9 \pm 0.4^{a}$ & $2.9 \pm 0.4^{b}$ & $1.7 \pm 0.3^{a}$ \\
\hline
\end{tabular}

Values in the same row with different letters are significantly different at $\mathrm{p}<0.05$. 
2011 season samples, the elemental concentrations were significantly different $(p<0.05)$ between the cultivars. The highest concentrations of potassium (4221 mg kg-1) and calcium (1009 $\mathrm{mg} \mathrm{kg}^{-1}$ ) were found in Sambo cultivar and the highest concentration of phosphorous was detected in Mammut $\left(1337 \mathrm{mg} \mathrm{kg}^{-1}\right)$. Fruits of $\mathrm{cv}$. Albida contained the highest concentration of magnesium (575 mg kg-1), sodium (53 mg kg-1) and manganese $\left(9.5 \mathrm{mg} \mathrm{kg}^{-1}\right)$, while fruits of cv. Dana contained the highest concentration of iron $\left(84.7 \mathrm{mg} \mathrm{kg}^{-1}\right)$. Concentrations of copper were comparable in all the cultivars, $2 \mathrm{mg} \mathrm{kg}^{-1}$ on average. A higher concentration of zinc was found in Albida and Bohatka (3.4 $\left.\mathrm{mg} \mathrm{kg}^{-1}\right)$.

Comparing berries from the different cultivars of Sambucus nigra harvested in 2011 and 2013, it was found that the average content of zinc, magnesium, calcium, sodium and potassium was higher in the 2011 season. The berries of Sambucus nigra cultivars harvested in 2013 had higher average concentrations of manganese, iron, phosphorus and copper than harvested in 2011. The climatic conditions for the harvest years are summarized in Figure 1. The average monthly temperature and precipitation were comparable in both harvest years. The average monthly duration of sunshine, however, was higher in 2011. The higher average monthly duration of sunshine in 2011 probably supported the photosynthetic processes in Sambucus nigra, which could have affected the content of some elements in Sambucus nigra fruits (AtKINSON et al. 2006).

In the present literature, there is scarcity of information on the elemental composition of Sambucus nigra. This study has shown that Sambucus nigra is an important source of macro- and microelements, especially magne-

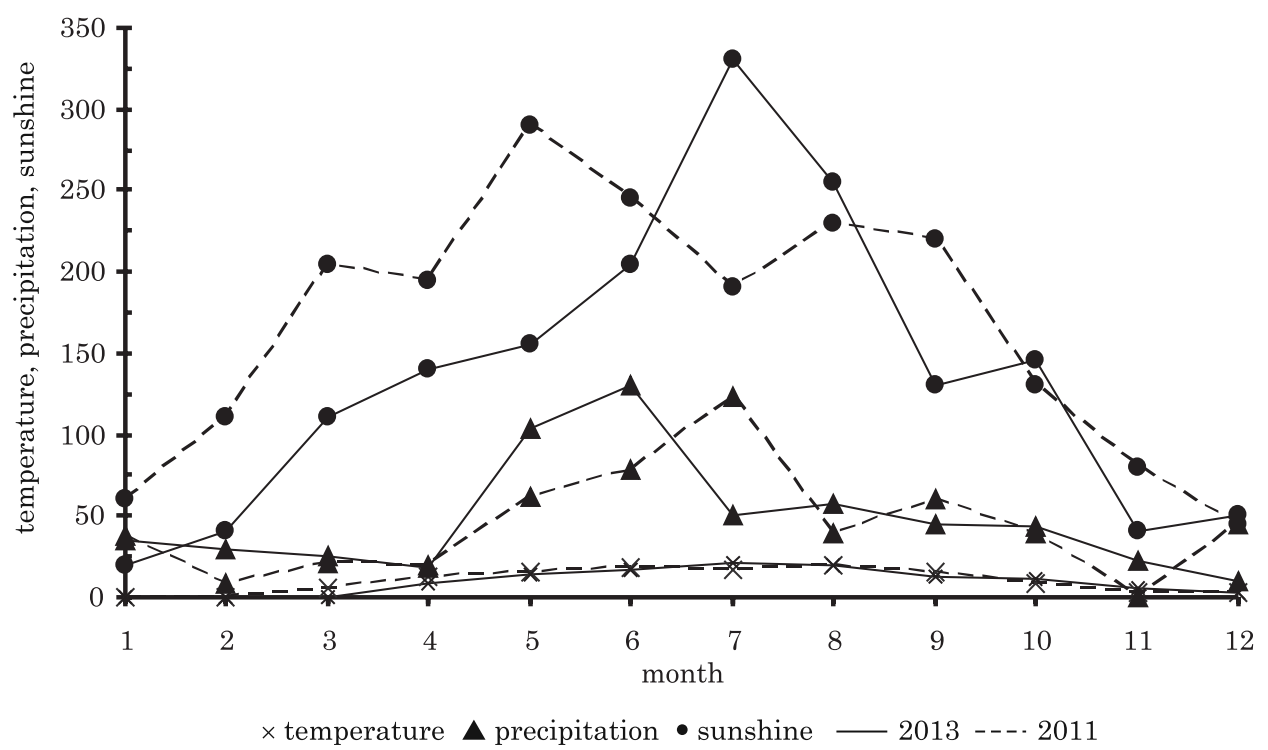

Fig. 1. Temperature $\left({ }^{\circ} \mathrm{C}\right)$, precipitation $(\mathrm{mm})$ and sunshine $(\mathrm{h})$ during the cultivation of Sambucus nigra (data from the Czech Hydrometorological Institute) 
sium, phosphorous, manganese, iron and copper. Magnesium, iron, phosphorous and manganese are needed in human nutrition for healthy teeth, normal blood clotting, proper nervous system functioning, energy metabolism and formation of haemoglobin (LukAski 2004, PREnTice et al. 2006, TAKedA et al. 2012), while copper is present in a large variety of enzymes with many functions, and is important for proper brain function (ScHEIBER et al. 2014, SiERPINSKA et al. 2014). On average, $100 \mathrm{~g}$ of Sambucus nigra fruits can cover $10 \%$ recommended dietary allowance for women and men (RDA) of potassium and calcium, $0.2 \%$ RDA of sodium, $15 \%$ RDA of phosphorous and magnesium, 30\% RDA of manganese, 20\% RDA of iron, 2\% RDA of zinc and $25 \%$ RDA of copper. CHIRIGIU et al. (2012) analyzed copper, zinc and iron in Sambucus ebulus L. The concentration of iron and zinc in Sambucus ebulus was significantly higher than in Sambucus nigra cultivars analyzed in this study; however, the concentration of copper was comparable in both elderberry species. KolodzIEJ et al. (2012) found a higher concentration of potassium, calcium and magnesium in Sambucus nigra compared to Sambucus nigra cultivars investigated in this study, while the concentrations of iron, manganese, copper and zinc were comparable to the average concentrations of those elements in Sambucus nigra cultivars determined in this study. Significantly lower concentrations of calcium and phosphorous in Sambucus nigra compared to this study were published by CHARLEBois et al. (2010).

\section{CONCLUSION}

This study revealed that Black elder fruits, in addition to being a good source of organic compounds, can also supply consumers with major and trace elements. Consumption of $100 \mathrm{~g}$ of Black elder fruits covers about $0.2-30 \%$ of the recommended dietary allowance of calcium, potassium, sodium, phosphorous, magnesium, manganese, iron, zinc and copper for women and men. The highest concentration of these elements was found in the cultivars Albida and Sambo. The elemental composition of Black elder fruits can differ with the year of harvest; however, the observed deviation in the mineral composition was usually less than $20 \%$. The results of this research can create additional criteria for selection of suitable cultivars grown by farmers for processing by the food industry as well as for local production and home processing.

\section{REFERENCES}

Atkinson A.D., Atkinson E. 2002. Sambucus nigra L. J. Ecol., 90: 895-923. DOI: 10.1046/j.13652745.2002.00698.x

Atkinson C.J., Dodds P.A.A., Ford Y.Y., Le Miere J., Taylor J.M., Blake P.S., Paul N. 2006. Effects of cultivar, fruit number and reflected photosynthetically active radiation on Fragaria $\times$ ananassa productivity and fruit ellagic acid and ascorbic acid concentrations. Ann. Bot., 97(3): 429-441. DOI: 10.1093/aob/mcj046 
Cavero R.Y., Akerreta S., Calvo M.I. 2013. Medicinal plants used for dermatological affections in Navarra and their pharmacological validation. J. Ethnopharmacol., 149: 533-542. DOI: 10.1016/j.jep.2013.07.012

Charlebois D, Byers P.L., Finn Ch.E., Thomas A.L. 2010. Elderberry: botany, horticulture, potential. Hortic. Rev., 37: 213-280.

Chirigiu L., Popescu R., Bubulica M.V., Popescu A. 2012. Determination of chromium, cooper, iron, zinc, cadmium and lead by graphite furnace atomic absorption spectrometry in seven phytopharmaceutical products. Rev. Chim., 63: 874-876.

Christensen L.P., Kaack, K., Frette, X.C. 2008. Selection of elderberry (Sambucus nigra L.) genotypes best suited for the preparation of elderflower extracts rich in flavonoids and phenolic acids. Eur. Food Res. Technol., 227: 293-305. DOI: 10.1007/s00217-007-0723-8

Folmer F., Basavaraju U., Jaspars, M., Hold G., El-Omar, E., Dicato, M., Diederich, M. 2014. Anticancer effects of bioactive berry compounds. Phytochem. Rev., 13: 295-322. DOI: $10.1007 / \mathrm{s} 11101-013-9319-\mathrm{z}$

Hubbermann E. M., Heins A., Stoeckmann H., Schwarz K. 2006. Influence of acids, salt, sugars and hydrocolloids on the colour stability of anthocyanin rich black currant and elderberry concentrates. Eur. Food Res. Technol., 223: 83-90. DOI: 10.1007/s00217-005-0139-2

Jakober L. Seruga M. Novak I. Medvidovic-Kosanovic M. 2007. Flavonols, phenolic acids and antioxidant activity of some red fruits. Deut. Lebensm.-Rundsch., 103: 369-378.

KAack K., Austed T. 1998. Interaction of vitamin $C$ and flavonoids in elderberry (Sambucus nigra L.) during juice processing. Plant Food Hum. Nutr., 52: 187-198. DOI: 10.1023/A:1008069422202

Kaack K., Frette X.C., Christensen L.P., Landbo A.K., Mayer A.S. 2008. Selection of elderberry (Sambucus nigra L.) genotypes best suited for the preparation of juice. Eur. Food Res. Technol., 226: 843-855. DOI: 10.1007/s00217-007-0605-0

Kolodziej B., Maksymiec N., Drozdzal K., Antonkiewicz J. 2012. Effect of traffic pollution on chemical composition of raw elderberry (Sambucus nigra L.). J. Elem., 17: 67-78. DOI: 10.5601/jelem.2012.17.1.06

LeE J., Finn Ch.E. 2007. Anthocyanins and other polyphenolics in American elderberry (Sambuclus canadensis) and European elderberry (S. nigra) cultivars. J. Sci. Food Agri., 87: 2665-2675. DOI: $10.1002 /$ jsfa.3029

LuKaski H.C. 2004. Vitamin and mineral status: Effects on physical performance. Nutrition, 20: 632-644. DOI: 10.1016/j.nut.2004.04.001

MA Y., Wu H. 2012. Chemical constituents of Sambucus L. Chinese J. Org. Chem., 32: 2063-2072. DOI: $10.6023 /$ cjoc201204025

Martinic E., Fotiric M. 2007. Selection of black elderberry (Sambucus nigra L.) and evaluation of its fruits usability as biologically valuable food. Genetika, 39: 305-314.

Ochmian I., Oszmianski J., Skupien K. 2009. Chemical composition, phenolics, and firmness of small black fruits. J. Appl. Bot. Food Qual., 83: 64-69.

Prentice A., Schoenmakers I., Laskey M.A., de Bono S., Ginty F., Goldberg G.R. 2006. Nutrition and bone growth and development. P. Nutr. Soc., 65: 348-360. DOI: 10.1079/PNS2006519

Scheiber I.F., Mercer J.F.B., Dringen R. 2014. Metabolism and functions of copper in brain. Prog. Neurobiol. 116: 33-57. DOI: 10.1016/j.pneurobio.2014.01.002

Schmitzer V., Veberic R., Slatnar A., Stampar F. 2010. Elderberry (Sambucus nigra L.) Wine: A product rich in health promoting compounds. J. Agric. Food Chem., 58: 10143-10146. DOI: $10.1021 /$ jf $102083 \mathrm{~s}$

Sierpinska T., Konstantynowicz J., Orywal K., Golebiewska M., Szmitkowski M. 2014. Copper deficit as a potential pathogenic factor of reduced bone mineral density and severe tooth wear. Osteoporosis Int., 25: 447-454. DOI: 10.1007/s00198-013-2410-x 
Takeda E., Yamamoto H., Yamanaka-Okumura H., Tuketani Y. 2012. Dietary phosphorus in bone health and quality of life. Nutr. Rev., 70: 311-321. DOI: 10.1111/j.1753-4887.2012.00473.x

Veberic R., JAkopic J.; Stampar F., Schmitzer V. 2009. European elderberry (Sambucus nigra L.) rich in sugars, organic acids, anthocyanins and selected polyphenols. Food Chem., 114: 511-515. DOI: 10.1016/j.foodchem.2008.09.080

Zafrilla P., Valero A., Garcia-Viguera C. 1998. Stabilization of strawberry jam colour with natural colourants. Food Sci. Technol. Int., 4: 99-105. DOI: 10.1177/108201329800400204 